\title{
Pricing strategies for new agricultural products
}

\author{
Vjosa Fejza Ademi' ${ }^{1}$, Ajtene Avdullahi ${ }^{2 *}$ \\ ${ }^{1}$ Economic Faculty, University of Prishtina Hasan Prishtina, Kosovo, ${ }^{2}$ Economic Faculty, University Isa Boletini in Mitrovica UIBM, Kosovo
}

\section{A B S T R A C T}

\begin{abstract}
Pricing strategies differ for each stage of the product life cycle. Although each stage of product life has its own peculiarities and challenges, the most difficult and challenging stage is setting prices for new products. Therefore, this was the reason which aroused our curiosity to do a research which is based on the theoretical and practical plane on this issue. Initially, the literature of various authors who have contributed in the field of pricing policy for products and services in general was reviewed. Based on this analysis, a very good foundation has been laid to understand the role and importance of pricing for new products, and the most used pricing strategies for this category of products have described and analyzed. From the theoretical analysis, conclusions have been drawn which have served as a supporting basis of the practical part of the paper. To make this research more thorough, we reviewed a special case study of the local manufacturing company Pestova I.I.c, which managed to launch several new products in the market of Kosovo and the Region. In this case study, the pricing strategies that this company has selected for the products launched in the market were analyzed. Finally, the conclusions that have emerged as a result of the analysis and the literature review and the concrete data obtained from the case study for the company Pestova are provided.
\end{abstract}

Keywords: Price; New products; Pricing strategies; Penetration strategy; Market sharing strategy

\section{INTRODUCTION}

Price is not just an ordinary number, written on the labels of products or services. It can appear in different forms and plays different functions, for example: travels, education, food, clothing, etc., are just some of the services and products that we pay in order to use them. Nykiel (2003), has given a simple definition of price, according to which price represents the monetary value of a product or service. Price is a direct reflection of the company's image, its market position and the perceived brand value of the products/services it offers. The price policy definition is one of the most important decisions in management as it affects corporate profitability and market competitiveness (Toni, Milan, Saciloto, \& Larentis, 2017).

For most of the history, according to Kotler and Keller (2012), prices have been set on the basis of negotiations between buyers and sellers. This culture of "bargaining" still finds application in certain areas of trade. Setting the same prices for all consumers represents a relatively new approach, which has marked its growth with the development of large-scale retail sales in the late nineteenth century. Understanding how to appropriately and smartly set prices presents a key skill for a business owner (Cornelisse, Graziani, \& Berntsen, 2020). Recent research indicates that the pricing of products is a costly and complex activity and that firms may differ in their capability to implement pricing strategies (Hallberg, 2017).

Creating and launching a new product on the market involves a very challenging and difficult path for the enterprise. How the product will be accepted in the market, how it will be positioned in relation to other competing products and how well it will be able to meet other environmental challenges, are some of the issues that require special care and analysis. A special part of this paper is the pricing of new products, which is a challenge in itself.

In shaping prices for new products, pricing policy plays a very important role, because it contains general, strategic and tactical dimensions. According to Jakupi (2000), when making pricing decisions for new products, a number of influential factors are set forth, such as: technological changes, degree of differentiation, intensity of purchasing frequencies, the level of combination of instruments of marketing mix, etc. 
In the first part of the paper, the literature of various authors was reviewed in order to understand and examine the role and importance of pricing policy on new products or services, as well as the most commonly used pricing strategies for this category.

While in the second part, a concrete case study for the company Pestova was taken in order to see and analyze how much importance they give to pricing their new products which they have launched in the Kosovo market, as well as which of the pricing strategies they chose in order to apply it to these products.

Furthermore, conclusions which were obtained from the findings from the review of various literature and from the data obtained from the case study analysis are provided. Finally, the last part includes the recommendations for the analyzed enterprise, which can be applied by the analyzed enterprise and serve for the improvement of this enterprise, as well as other enterprises of the same sector.

\section{LITERATURE REVIEW}

Pricing requires a lot of dedication and work on the part of the respective managers, because any wrong decision on pricing can be fatal for the company. According to authors Nagle and Hogan (1995), if effective product development, promotion, and distribution are the seeds sown for business success, then effective pricing contributes to reaping of this success sown for the business.

Strong competition over the last few years, has influenced the increase in diversity, varieties and complexities during the new product introduction (NPI) from "very simple" to "very complex" (Prasad, 1997). Before launching a new product, product managers must determine an appropriate marketing strategy (Bruce, 2014).

Although the time in terms of market has shrunk (Prasad, 1994) still, the most difficult step for enterprises in launching new products in the market, is understanding the real level of their innovation (Marn, Roegner, \& Zawada, 2004). Schumpeter was the first author to write in his books since 1911 about the meaning of innovation without using the word innovation but describing it as "doing new things or doing things that have already been done, in a new way." (Schumpeter, Opie, \& Elliott, 1983). Innovations have been classified by numerous authors as innovations in products, processes, marketing and organizational innovation (OECD, 2005; Oke, Burke, and Myers, 2007; Chetty and Stangl, 2010; Gunday, Ulusoy, Kilic, and Alpkan, 2011; Rowley, Baregheh, and Sambrook, 2011).
Marketing innovations can be applied in new products but also in the existing ones (Chetty \& Stangl, 2010). Marketing innovation plays an important role for business to "identify growth opportunities, set up efficient processes to create and launch new products and manage the launch and post-launch of marketing plan" (Three-brains, 2021). In addition, innovations in marketing lead to product development at the horizontal level by modifying the packaging design, promotion strategies and product positioning of the existing products which affect the increase in sales volume and profit growth (Oke, Burke, \& Myers, 2007).

The pricing strategy is developed mainly from three aspects: premium pricing, discount pricing, and dynamic pricing (Feng, Hu, Yang, \& Liu, 2019). Pricing of the new products remains highly important. The product prices that the company sets affect the likelihood of customers to buy a company's products, their perceived value of products and, of course, the total firm's profits (Cornelisse, Graziani, and Berntsen, 2020). Thus, firms use pricing and advertising strategies as key tools to convince consumers to embrace product innovation (Bruce, 2014).

Great attention in the literature lately is paid to the consumer behavior on innovation adoption (Hoegg and Alba, 2011; Bruce, 2014). According to Marn, Roegner, and Zawada (2004), the new product can be classified into three groups, depending on the level of its innovation:

- Revolutionary products: are highly innovative products, which create their own markets and for which there are no competitive products that can be compared to.

- Evolutionary products: include those products that represent a new, improved version or added elements of a product that has been existing in a given market.

- "me - too" products: are those products which are the same as existing competing products in the market. Therefore, these products do not offer any additional benefits to consumers, but only try to provide additional replacement products.

Fig. 1 classifies companies based on the types of new products they can offer:

According to Kotler, Armstrong, Saunders, and Wong (1999), new products can be of two types: new products that mimic existing products, and completely new, innovative products that have not previously existed in the market. According to them, the company which plans to develop a new imitation product, faces the problem of product positioning (Kotler, Amstrong, Saunders, \& Wong, 1999). Fig. 2 presents four possible strategies for positioning new imitation products. 


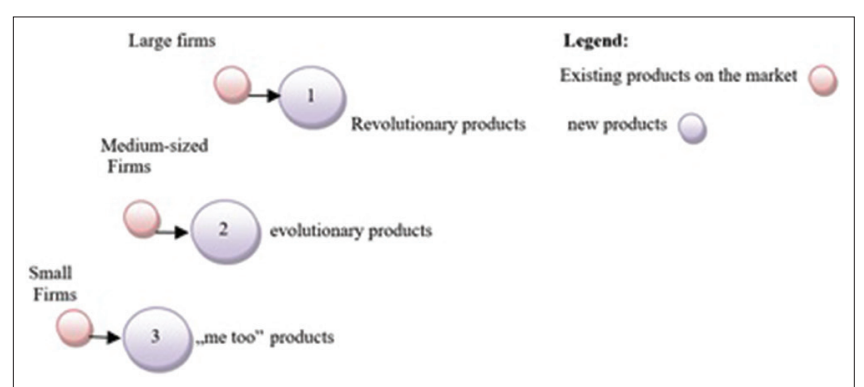

Fig 1. Three classifications of new products according to the level of innovation (Source: Marn, Roegner, and Zawada (2004)

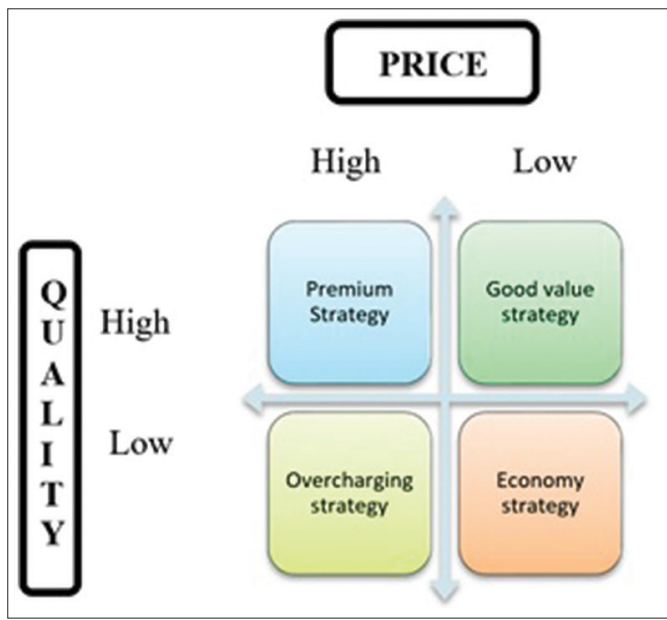

Fig 2. Four price-positioning strategies. Source: Kotler, Amstrong, Saunders, and Wong (1999)

As can be seen from the Fig. 2, companies that choose to offer high quality and high priced products adopt premium pricing strategy (Kotler and Armstrong, 2019). Whereas, the companies that choose the other extreme, offering low quality products and low prices, use the economic strategy.

On the other hand, the strategy based on good value, is used by those companies that offer high quality products, but at low prices. This strategy is typically suitable for companies that want to penetrate the market en masse at low prices. (Kotler and Armstrong, 2019). And the latter strategy, known as the overcharging strategy, is used by companies that offer low quality but high priced products. This strategy, according to Kotler, Armstrong, Saunders and Wong (1999), is not recommended to be used due to the fact that consumers can quickly realize that they are paying more than the value that the product actually has. And this can then lead to the creation of a negative image, both for the enterprise itself and for its products.

When it comes to companies that decide to bring completely new products, which did not exist as such before in the market, they will face the challenge of setting initial prices. Regarding pricing new products, according to Kotler and Armstrong (2013), there are two types of strategies:

1. Pricing strategy with market segmentation, or as it is otherwise known by the terms "Price shearing", "Market filtering strategy", or "Price skimming strategy";

2. Pricing strategy for market penetration, or as it is otherwise known as the penetration strategy.

According to Pride and Ferrell (2003), companies that choose market-based pricing strategy set the highest possible prices for their products that consumers who want these products can pay for. This strategy enables companies to have great flexibility in the base prices when introducing new products to the market. Kurtz (2008) emphasizes that this strategy can be used effectively if there is no or scarce competition for new products or services, because when competition increases, then the initial high price will drop. In addition, Blythe (2005), emphasizes that the skimming strategy can be used by those firms, which have the capacity to develop advanced technological products. Among others, according to Ceku and Reshidi (2006) this strategy can be used by firms in a situation when the company is positioned in the top range and thus expects to benefit from raising the image, in order to ensure high margins per unit.

According to Nagle and Hogan (1995), consumers who receive new products with high initial prices belong to the group of consumers who are not price sensitive. Therefore, they are willing to pay a high price to get more value from the product/service. This category of consumers can include those who value the unique attributes of the product, those who travel for business and their expenses are paid by the legal entity they represent, etc. The advantage of using this strategy, according to Blythe (2005), lies in the fact that the costs of designing and developing a new product are returned very quickly, so that later, when the product moves to the next stages of its life cycle, it can be sold at a lower price that approximates the marginal cost of production. This means that new competitors will find it difficult to enter the market afterwards, because they too will have to be able to cover the production costs of their products, which with the new low price set from the enterprise in question, will have quite a problem achieving it.

In practice, many marketers often think that pricing strategy with market segmentation is not feasible when production economies are high. According to Nagle and Hogan (1995), this view is not entirely correct, because even if only $15 \%$ of the market share are not price sensitive, and this market share is taken care of only by a company that offers high value products but at high prices, then it can provide large 
profits equal to, or sometimes even higher, than companies serving the wider market, i.e. $85 \%$ of the rest of the market which are price sensitive.

On the other hand, according to Czinkota (2000), companies that want to set the price for their new products below their real value, use the so-called market penetration strategy. This does not mean that the products will have low prices, but that their price in relation to the quality they possess, is low. Chatterjee (2009), highlights some of the conditions under which this strategy can make sense, such as:

- Target market consumers need to be price sensitive;

- Production and distribution costs should fall with the increase in sales volume, taking advantage of economies of scale and the effects of the experience curve;

- The low price should help to prevent the risk of entry of new competitors.

Nagle and Hogan (1995), point out that the penetrating pricing strategy can be successful for a company only if its competition does not have the opportunity to compete at lower prices than those set by the company for its products. According to them, this strategy can be successful in two situations: 1 . When the company has an advantage in production and distribution costs and/or when it has an advantage in a particular resource, which is inaccessible to the, and as a result they do not enter into the price war at all; and 2. When the company is currently small, which can increase sales enough to trigger a response, but without affecting and hurting the sales of its competitors (Nagle \& Hogan, 1995).

New and innovative products are of particular importance to enterprises; on the other hand only a few companies treat innovation in pricing as seriously as product innovation or business model innovation (Hinterhuber \& Liozu, 2014). LaPlaca (1997) pointed out that price is so important to the firm's success that one wonders why pricing has not received more attention. Buffett (2011) rates the businesses on their ability to raise prices. Further Waren Buffet stresses that "if you've got the power to raise prices without losing business to a competitor, you've got a very good business" (Wachtel, 2011). Hinterhuber and Liozu (2012) found that pricing power is not destiny, but a learned behavior, further it is a skill. Liozu and Hinterhuber pointed out that there is a gap in the literature regarding pricing methods and firm performance (2013). Businesses may have different approaches to pricing but most of them fall into one of three categories: cost-based pricing, competition-based pricing or customer value-based pricing (Hinterhuber \& Liozu, 2012)
Obesity and overweight are one of the most serious problems of humanity worldwide. Thus, the choice of food, meals and snacks requires special care. From the literature review we found that some authors also dealt with the introduction and penetration of healthier and lower fat snack products in the market. French, et al., (2001) stress that promoting desired food choices in communitybased environments by lowering prices is a very effective method which can further ensure maintaining of the overall profitability. It is the task of marketers to provide the easiest and most innovative distribution channels of lowfat products to the end-users. In their study, French et al., (1997) examined the role of price on purchases of low-fat snacks from vending machines. They found that reducing relative prices may be effective in promoting lower-fat food snacks choices in the population (French et al., 1997).

The penetrating pricing strategy requires from companies to have sufficient resources to support the rapid growth of production, distribution and promotion of new products. According to Chatterjee (2009), companies that apply this strategy sacrifice the generation of short-term profit for long-term benefits in the future in terms of low costs and a strong market position, which can then serve as a very important resource for creating competitive advantages. We found that there is a gap in the literature regarding the pricing strategy of new products from the agricultural sector in general and in particular for the potato production and processing company from a transition economy. We believe that this research with a single case study approach will bring experience regarding the pricing strategies of new products from the agricultural sector, more specifically from a company for the production of potato products and thus contribute to filling this gap in the literature.

\section{METHODOLOGY}

In the first part of this paper, data were collected from secondary sources, such as: literature of various authors and various publications in scientific journals. These data and information collected, through the method of analysis and description enabled us to examine and draw conclusions about the understanding of the role and importance of the design and implementation of sound pricing strategies for new products, which certain companies want to launch in the market. Among other things, the method of comparing data obtained from the literature of different authors was used with regards to the definitions and concepts that each of them has provided. The purpose of the entire work was to apply comparison in order to reach to the concept, idea and the best process of designing and implementing the most effective pricing strategies for new products, so that our companies can achieve market successes. 
Of particular importance in the second part of the paper is the analysis and review of a specific case study of a local manufacturing company Pestova, which has expanded the range of its products with some new products, which have been gradually introduced to the market since the end of 2014. Most of the data related to this company are provided from the interview conducted with the general manager of this company, and some additional data were obtained from the sales manager, the accountant and the official website of the company. Then, this information was analyzed and reviewed to come to certain conclusions regarding the strategies that this company has chosen for pricing its products, which are new to our market.

In addition, the paper used the method of synthesis, induction and deduction, mainly in the last part where, from all the material and practical research carefully broken down, analyzed and reviewed, certain conclusions have been reached.

Results from the case study for the company Pestova In Kosovo there are 129,220 agricultural holdings (agricultural households and agricultural legal entities), while 14,954 agricultural holdings are in the Mitrovica region (KAS, 2020). In the first quarter of 2021 from 2,078 new registered businesses in Kosovo there were 79 from the section of Agriculture, forestry and fishing economic activity (KAS, 2021). Pestova is the only potato production and processing company from all businesses in the agricultural sector in Kosovo.

The manufacturing company Pestova was originally established as a family business in 1991 by the Kasumi family, and was re-registered immediately after the end of the Kosovo war in 1999. However, the production tradition of this family dates back to the early 50s. Their activity started with the production and sale of potatoes in an area of two hectares. 1 Now there are about 450 hectares of cultivated area, of which 200 hectares are owned by the company, another 200 hectares are owned by private farmers who work and give their land by agreement and 50 hectares are in Albania. The reason for the contracting of farmers' lands in Albania is that the climate there allows the early varieties to be planted in January, while in Kosovo they start to be planted only in April and May. This enables the Company Pestova to provide and manage the raw material without any problems.

The selection of farmers is done every year based on the criteria set according to the GLOBAL GAP standard ${ }^{2}$,

1 http://www.pestova.org/pestova/index.php?option=com_conte $\mathrm{nt \& view}=$ article\&id $=47 \&$ Itemid $=54$ (December, 2020)

2 http://www.pestova.org/pestova/index.php?option=com_conte $\mathrm{nt} \& v i e \mathrm{w}=$ article $\& \mathrm{id}=47 \&$ Itemid $=54($ December 2020) where to each of them the company offers quality seeds, different varieties of potatoes, tips for applying new agricultural practices, use of fertilizers, etc.

A very important fact worth noting for this company is that since 2008, the European Bank for Reconstruction and Development (EBRD), is a co-shareholder of this company ${ }^{3}$.

Today, the Company Pestova has managed to become a vertically integrated enterprise, which means that the process of production of potato seed, cultivation of potatoes for consumption and processing, sale and distribution of potatoes and its products, are conducted by the company itself. As such, it is currently the only domestic manufacturing enterprise which has foreign producers as competitors. A negative fact that characterizes this company is the lack of a proper marketing department in its organizational structures. The role of the marketing department has been entrusted to the sales department, which may not have the necessary competencies and knowledge to properly manage the marketing tasks and duties.

Pestova has managed to sell its products not only in the market of Kosovo, but also in the region, such as Albania, Macedonia, Bosnia and Herzegovina and has already gradually started to enter the market of Bulgaria. For the Kosovo market, the distribution of products to retail outlets is carried out by the company itself, while in the markets of the region, it has reached contractual agreements with wholesalers of the respective countries, who then distribute the products to retailers.

The business activities of the Company Pestova are:

- Import, production and sale of potato seed;

- Sale of mechanism, agricultural inputs;

- Production and sale of fresh potatoes;

- Processing of potatoes in various forms of products, such as: Chips, Snacks and Flips.

This paper covers only the study of the potato processing in new forms of products. From a survey conducted by the Company Pestova on its official website, we can see which product category of this company consumers prefer most.

As seen in the Fig. 3, of the 409 consumers who participated in this survey, $77.3 \%$ stated that they prefer Chips products. One of the reasons that consumers prefer this product category, according to the sales manager of this company is the fact that Chips products were the first potato products processed by the Company Pestova. Therefore, consumers

3 http://www.pestova.org/pestova/index.php?option=com_conte nt\&view $=$ article\&id $=50 \&$ Itemid $=59$ (December 2020) 
have been familiar with these products for years, while other products, such as Flips and Snacks are the new category of products that this company has started to launch in the markets where it operates.

At the beginning of 2014, the management of the Company Pestova began to consider the possibility of expanding the range of products produced. This signal comes as a result of the data they have received from points of sale for competitors' products. This company tries to produce products similar to those of competitors, but offering some added value to customers. This company, unfortunately, does not do any formal market research, as any company aiming to conquer the market should do, but only collects information from points of sale through its agents. For example, if a certain point of sale requires a larger quantity of one of the products of the company Pestova, based on this it is estimated that consumers like the product in question and thus can increase the amount of its production.

From the end of 2014, the Company Pestova launched three new products in all markets where it has expanded its activity. Whereas in the beginning of 2015, it launched another new product. The types of products, the period of their launch in the market, their price, as well as the initial quantities of their sale are presented in the following table:

As can be seen from the Table 1, all of these products have a relatively cheap price, based on the products of other competitors offering similar products in the markets where

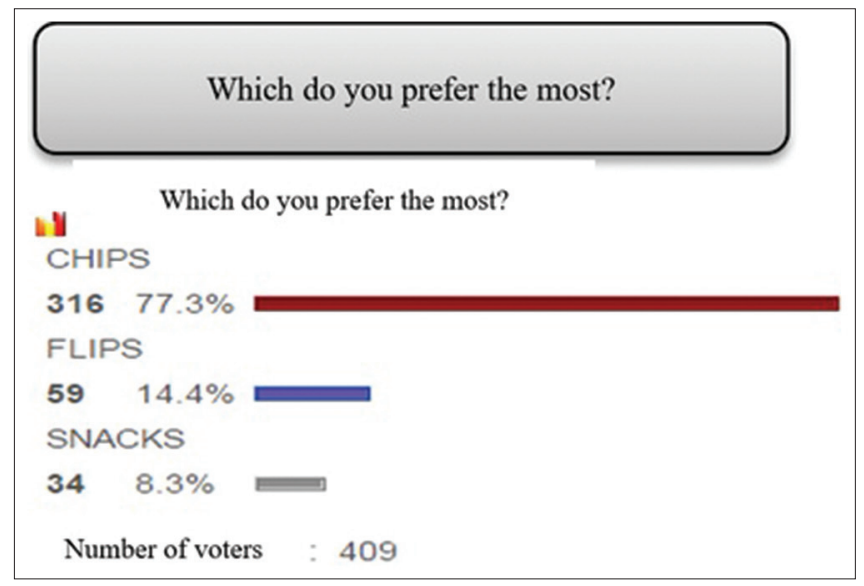

Fig 3. The results of the survey with consumers from the official website of the company Pestova this company operates. In addition, it has been observed that the quantity of products sold, since their launch for the first time in the market, has been increasing for all products on average by $5 \%$. This fact is a very positive indicator for the company, especially for these new products that this company has introduced in the market, because it shows that they have been positively received by target customers.

The Company Pestova has not offered any product that would be totally new, i.e. completely different from existing competing products in our market. Hence, according to Marn, Roegner and Zawada (2004), this company is part of the type of companies that offer evolutionary products, i.e. products which have similar characteristics to competitors' products, but differ in some attributes, such as taste, quality, product design and packaging, etc. To make it clearer, we recall once again the chart of the classification of new products according to the degree of innovation, where the positioning of the Company Pestova is presented in Fig. 4.

In order to enter with its new products in the markets where it operates, Company Pestova has used the pricing strategy for market penetration, otherwise known as the penetration strategy. According to Czinkota (2000), companies that want to set the price for their new products below their real value, use the so-called market penetration strategy. The same tactic was used by the Company Pestova, which for its new products, has set lower prices than the competition, but without losing the value and quality of products.

The reasons why this company has chosen exactly this pricing strategy are: the sensitivity of the target customers to the price, the massive and rapid penetration to the target customers, the prevention of the entry of new competitors, etc. Hence, customers for this category of products are sensitive to changes in price, so they prefer quality products but at low prices. In addition, the goal of the Company Pestova is to reach quickly and massively to the target customers by offering good quality products but at lower prices than competitors.

From 2015 until 2019, the Company Pestova managed to launch several other new products, such as: Snacks, Stix and Bugles. All these products are produced with at least 2-3 different flavors, in order to suit the different tastes

Table 1: Data on new products of the Company Pestova

\begin{tabular}{lcccc}
\hline Product type & Period of launch in the market & Price & $\begin{array}{c}\text { The initial quantity of sales in the market } \\
\text { for the first month }\end{array}$ & $\begin{array}{c}\text { Percentage of sales growth } \\
\text { in subsequent months }\end{array}$ \\
\hline Dino & September 2014 & $0,075 €$ & 5000 pieces & $6 \%$ \\
Tortilla & October 2014 & $0,30 €$ & 2000 pieces & $4 \%-5 \%$ \\
Pop Corn & December 2014 & $0,075 €$ & 2000 pieces & $3 \%-4 \%$ \\
Crispy & January 2015 & $0,16 €$ & 5000 pieces & $6 \%-7 \%$ \\
\hline
\end{tabular}




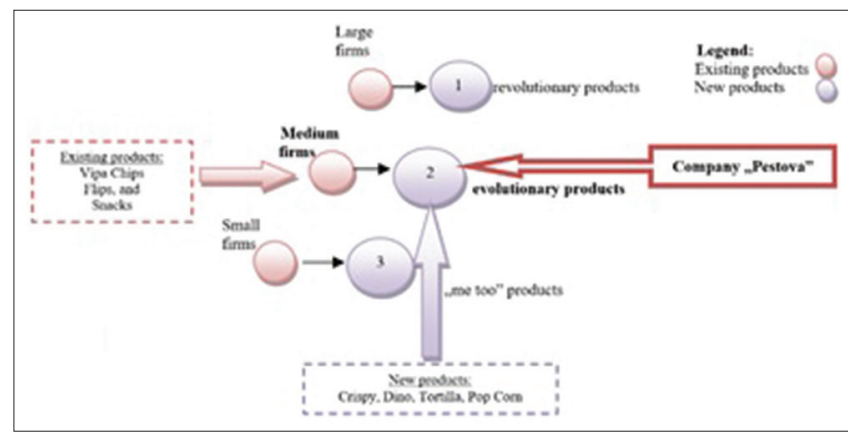

Fig 4. Three classifications of new products according to the degree of innovation. Source: Adapted from Marn, Roegner, and Zawada (2004)

and preferences of their customers. For these products, it has used the same strategy as for the products launched earlier and described above. This is mainly due to the fact that these products are also evolutionary products.

In Kosovo, there are no other potato production and processing enterprises except Pestova. Other products that compete with the products of this company, are imported, i.e. they are produced in foreign countries. Therefore, based on this fact, the Company Pestova has managed to make good use of the position it enjoys in the potato production and processing sector in Kosovo, by absorbing donations and subsidies from local governmental and non-governmental authorities, as well as from other foreign organizations. All these benefits that this company has received, have helped it to be able to produce products of good quality and at much lower prices than competing imported products. Snacks and other food products worldwide use mostly palm oil. Palm oil contains saturated fat (Kadandale, Marten, \& Smit, 2019). The World Health Organization (WHO) and the Food and Agriculture Organization (FAO) described the evidence linking saturated fat consumption with increased risk of cardiovascular disease as convincing (WHO/FAO, 2003). Pestova differentiates from the competitors as it uses only sunflower oil for the production of potato chips and its products are palm oil-free. This can be considered as a competitive advantage over its competitors. Most of the snack producers use palm oil, which makes their products are harmful to human health, especially for children.

Pestova already managed to gain a stable position in the country, by using the penetration strategy for pricing its new products in the market, it has managed to discourage the entry of new competing manufacturers in this sector. This fact confirms the theory of Nagle and Hogan (1995), who emphasize that the penetrating pricing strategy can succeed for a company only if its competition does not have the opportunity to compete with lower prices than those set by this company to its products. Therefore, as long as Pestova will be able to provide sufficient resources to cope with the rapid growth of production, distribution and promotion of its new products, it will not lack the positive results of the implementation of this strategy.

Even though, according to the sales manager of this company, they often have to sacrifice the generation of short-term profit, it is worth it, because the benefits generated in the long run are many times higher than those in the short run. This way they manage to create a competitive advantage by creating a strong position in the markets where the products of this company are present.

\section{CONCLUSIONS AND RECOMMENDATIONS}

\section{Conclusions}

Based on the findings from the paper, the literature cited in the paper but also from the data extracted from the case study for the Company Pestova in Kosovo, we can conclude that, if a company wants to survive and compete in today's dynamic and increasingly global market, they definitely need to create the place and space for the marketing department in their organizational structures.

Without a functioning marketing department in the enterprise, there can be no proper market research to discover the needs and requirements of the target customers. It will also be even more difficult to achieve the proper development of new products that would best meet the identified needs and requirements of customers.

Another difficulty that companies which do not pay due attention to the marketing department in their enterprises may face is the planning and implementation of proper pricing forms and strategies for new products that they plan to launch in market. As noted in the literature review, price is only one of the elements of the marketing mix, but it has a very important role, because it is the only element through which the company generates revenue, while other elements create costs. In addition, it is important to know that customers in the Kosovo market, especially when it comes to the potato processing sector, are very price sensitive. Therefore, the chosen strategy for pricing new products will automatically affect the positioning of the company and its products in the market.

Based on the findings of this paper, we can conclude that only effective pricing strategies for new products are the key to the success of producers in Kosovo, and that these producers should be more oriented to the practical implementation of pricing strategies presented in this paper, in order to successfully fulfill the intended goals and tasks. Only in this way will they be able to generate 
greater sales and profits, and will be able to create a stable position in the target market.

\section{Recommendations}

Producers in Kosovo, especially the Company Pestova that was taken as a case study, must make radical changes in their activities by giving them their due place and role, especially sales and marketing activities, because today in terms of high competitiveness in the market, it is easy to produce but it is much harder to sell. And to make the sale easier and more successful, the production activity must be adapted to that of marketing by analyzing the needs, desires and requirements of customers and adapting and meeting them. Therefore, in conclusion, the recommendations from the study made for the Company Pestova, but also for other producers in Kosovo of the same sector, can be summarized in the following points:

- They should pay attention and give its due to marketing department in their companies so that the information on the market, buyers, suppliers, competition, new products, can come from the marketing/sales department, i.e. from people specialized for this purpose;

- They should base their activity on sustainable marketing strategies which would faster and more easily lead to profit;

- They should make efforts to become more creative and innovative, trying to produce and offer products that would be revolutionary for the Kosovo market and not just "imitation" products and modified or evolutionary products. This would enable them to become leaders and unique in the market.

- They should expand the range of products by producing products with less fat and calories which would be consumed not only by young people and children but also by elderly consumers. In this way the Company Pestova would expand the segments of the target markets, which would in turn increase sales and profits.

\section{Paper limitations}

Despite the contribution of this paper to bringing experiences regarding the pricing of new products launched in the Kosovo market, the paper also has some limitations, mainly in the part of the case study analysis, which have created difficulties in gathering all the proper, accurate and necessary information for the full understanding of this paper. Some of the limitations can be listed as follows:

- Lack of a concrete written plan for new product development. This has created problems, because all the data received from the Company Pestova regarding the way and steps that this company has followed to develop and launch its new products in the market, have been only in verbal form. The information was provided by interviewing face to face the general manager of this company, the sales manager and the accountant. From the sales manager were obtained some tabular data regarding the quantities of new products that were produced and sold in the first months of their launch in the market, and the percentages of growth of their production and sales in the market for the following months. From the accountant we have obtained sales prices for each of these new products of this company.

- Lack/Inaccessibility to complete data and information. This presents one of the biggest challenges we faced during the research in this paper. The biggest challenge has been in obtaining the data related to budget planning, i.e. how much they have spent on average for the production, launch, sale and promotion of these new products in the market.

- Reliance on only one case study. The reason why only the Company Pestova was analyzed is based on the fact that in our country it is quite difficult to find two companies of the same sector that are expected to launch both new products on the market in the same period of time. In fact, the Company Pestova is the only potato production and processing company in Kosovo. Only foreign producers are competitors to its products.

\section{REFERENCES}

Kotler, P. and G. Amstrong. 2013. Parimet e Marketingut. Botimi i 13te, UET Press, Tirane, .

Blythe, J. 2005. Essentials of Marketing. $3^{\text {rd }}$ ed. Pearson Education Limited, England.

Bruce, L. C. 2014. Critical decisions in new product launch: Pricing and advertising strategies on consumer adoption of green product innovation. Asian J. Technol. Innov. 22(1): 16-32.

Ceku, B. and N. Reshidi. 2006. Marketingu. Universiteti Mbreteror "lliria", Prishtine.

Chatterjee, R. 2009. Strategic pricing of new products and services. In: Handbook of Pricing Research in Marketing, Cornell University, United States, pp. 169-215.

Chetty, S. K. and Stangl. 2010. Internationalization and innovation in a network relationship context. Eur. J. Mark. 44(11/12): 17251743.

Cornelisse, S., M. L. Graziani and M. Berntsen. 2020. In: C. O (Ed.), Growth Strategy: Pricing Strategies for Farm and Food Business, Pennsylvania, United States. Available from: https:// www.extension.psu.edu/growth-strategy-pricing-strategies-forfarm-and-food-business.

Czinkota, M. 2000. Marketing-the Best Practices, The Drynden Press, Fort Worth.

Feng, S., X. Hu, A. Yang and J. Liu. 2019. Pricing strategy for new products with presales. Mathemat. Prob. Eng. 2019: 1-13.

French, S., R. Jeffery, M. Story, P. Hannan and M. Snyder. 1997. A pricing strategy to promote low-fat snack choices through 
vending machines. Am. J. Public Health. 87(5): 849-851.

French, S., R. Jeffery, M. Story, K. Breitlow, J. Baxter, P. Hannan and P. Snyder. 2001. Pricing and promotion effects on low-fat vending snack purchases: The CHIPS study. Am. J. Public Health. 91(1): 112-117.

Gunday, G., G. Ulusoy, K. Kilic and L. Alpkan. 2011. Effects of innovation types on firm performance. Int. J. Prod. Econ. 133(2): 662-676.

Hallberg, N. L. 2017. The micro-foundations of pricing strategy in industrial markets: A case study in the European packaging industry. J. Bus. Res. 76: 179-188.

Hinterhuber, A. and S. Liozu. 2012. Is It Time to Rethink Your Pricing Strategy? MITSloan Management Review, Massachusetts.

Hinterhuber, A. and S. M. Liozu. 2014. Is innovation in pricing your next source of competitive advantage? Bus. Horiz. 57(3): 413423.

Hoegg, J. and J. W Alba. 2011. Seeing is believing: The influence of product form on perceptions of functional performance. J. Prod. Innov. Manage. 28(3): 346-359.

Jakupi, A. 2000. Bazat e Marketingut. Universiteti i Prishtines, Prishtine.

Kadandale, S., R. Marten and R. Smit. 2019. The palm oil industry and noncommunicable diseases. Bull. World Health Organ. 97: 118-128.

KAS. 2020. Kosovo Agency of Statistics. Available from: https://www.askdata.rks-gov.net/PXWeb/pxweb/en/ askdata/askdata__15\%20 Structural $\% 20$ business $\% 20$ statistics/?rxid=44f28e59-f222-40cd-adf4-2c4b8b2c9386.

KAS. 2021. Kosovo Agency of Statistics. Quarterly Bulletin, Q1; 2021. Available from: https://www.ask.rks-gov.net/en/kosovo-agencyof-statistics/add-news/buletini-tremujor-tm1-2021.

Kotler, P. and G. Armstrong. 2019. Principles of Marketing. $17^{\text {th }}$ ed. Pearson, London, UK.

Kotler, P. and K. L. Keller. 2012. Marketing Management. 14 ${ }^{\text {th }}$ ed. Prentice Hall, New Jersey.

Kotler, P., G. Amstrong, J. Saunders and V. Wong. 1999. Principles of Marketing. $2^{\text {nd }}$ ed. Prentice Hall Europe, European.

Kurtz, D. L. 2008. Contemporary Marketing. $13^{\text {th }}$ ed. South-Western, Cengage Learning, United States.

LaPlaca, P. J. 1997. Contributions to marketing theory and practice from industrial marketing management. J. Bus. Res. 38(3): 179198.
Marn, M. V., E. V. Roegner and C. C. Zawada. 2004. The Price Advantage. John Wiley \& Sons, Inc., New Jersey.

Nagle, T. T. and J. E. Hogan. 1995. The Strategy and Tactics of Pricing. A Guide to Growing More Profitably. Prentice Hall, New Jersey, USA.

Nykiel, R. A. 2003. Marketing Your Business. A Guide to Developing a Strategic Marketing Plan, The Haworth Press, Inc., New Jersey, USA.

OECD. 2005. Oslo Manual Guidelines for Collecting and Interpreting Innovation Data. $3^{\text {rd }}$ ed. OECD and European Commision, OECD and Eurostat, Paris.

Oke, A., G. Burke and A. Myers. 2007. Innovation types and performance in growing UK SMEs. Int. J. Operat. Prod. Manage. 27(7): 735-753.

Prasad, B. 1994. Competitiveness analysis of early product introduction and technology insertion. Manuf. Sci. Eng. 1: 121123.

Prasad, B. 1997. Analysis of pricing strategies for new product introduction. Pric. Strat. Pract. 5(4): 132-141.

Pride, W. M. and O. Ferrell. 2003. Marketing. Concepts and Strategies. $12^{\text {th }}$ ed. Houghton Mifflin Company, Boston, New York.

Rowley, J., A. Baregheh and S. Sambrook. 2011. Towards an innovation-type mapping tool. Manage. Decision. 49(1): 73-86.

Schumpeter, J. A., R. Opie and J. E. Elliott. 1983. The Theory of Economic Development: An Inquiry into Profits, Capital, Credit, Interest, and the Business Cycle, Transaction Publishers, New Brunswick, New Jersey.

Toni, D. D., G. S. Milan, E. B. Saciloto and F. Larentis. 2017. Pricing strategies and levels and their impact on corporate profitability. Rev. Admin. 52(2): 120-133.

Three-brains. 2021. Marketing Innovation. Available from: https:// www.three-brains.com/marketing/brand-strategy-skills/ marketing-innovation.

Wachtel, K. 2011. Insider. Warren Buffett: There's Only One Thing That Matters To Me When I'm Investing In A Company, New York, USA. Available from: from https://www.businessinsider. com/warren-buffett-pricing-power-beats-good-managementberkshire-hathaway-2011-2. [Last accessed on 2021 Mar 13].

World Health Organization, Food and Agriculture Organization. 2003. Diet, Nutrition and Prevention of Cronic Diseases, World Health Organization, Food and Agriculture Organization, Geneva. 